\title{
Plant diversity and stand structure comparison of Mikania micrantha invaded and non-invaded tropical Shorea robusta forest
}

\begin{abstract}
S. Basnet ${ }^{1 *}$, D. B. Chand ${ }^{1}$, B. H. Wagle ${ }^{2}$ and B. Rayamajhi ${ }^{1}$
Mikania micrantha is considered to be the most problematic in terrestrial ecosystem in Eastern and Central Nepal. Despite the current situation of the Mikania invasion, quantitative data on the impacts and scale of the problems are lacking for the country. Due to the lack of information regarding scale of invasion, the stakeholders have not put forwarded the proper control mechanism of the species. This paper has made an attempt to analyze the scale of invasion through the comparison of plant biodiversity and basal area per hectare as the significance of stand structure between Mikaniainvaded and non-invaded tropical Shorea robusta forest areas. This study was conducted in Barandabhar Buffer Zone Forest of Chitwan National Park. Sampling and measurement was conducted in both the invaded and non-invaded forest areas. The stand structure of both the invaded and non-invaded areas were compared in terms of different parameters like seeding density, sapling density, pole basal area per hectare and tree basal area per hectare. Statistical analysis showed that there is significant impact of Mikania on plant diversity at seedling and sapling stages. There is negative effect of Mikania on stand structure of the forest. Hence, there is urgent need to control the invasive weed so as to control further invasion and to conserve biodiversity and productivity.
\end{abstract}

Key words: Basal area, invasion, Mikania micrantha, plant diversity

$\mathrm{N}$ epal is well known for its diverse flora and many plant species are endemic to the country. However, some of them have been introduced unintentionally owing to the landlinked situation of the country. In a country like Nepal, an infestation of plant invasive species makes rural livelihoods more vulnerable because economy of farming community heavily depends upon forest resources (Adhikari et al., 2004), and an introduction of such invasive plants are likely to influence upon the native ecosystem.

In Nepal, altogether 166 alien plant species are invading different ecosystems including forest, grassland, agricultural land and wetlands (Tiwari et al., 2005). Mikania micrantha (Kunth), a tropical plant belonging to the family Asteraceae, is a perennial, sprawling vine with a wide distribution in the Neo-tropics, which extends from Mexico to Argentina (Holmes, 1982). It is one of the top 10 worst weeds in the world (Holm et al., 1977). It is a fast growing, perennial climber, commonly called mile-a-minute weed, because of its vigorous and rampant growth habit. It has been reported to grow to $27 \mathrm{~mm}$ a day (ISSG, 2005). It is a pernicious weed in crops such as rubber, cacao, oil palm, coconut, banana, pepper and tea, and usually grows profusely in places receiving high rainfall or humid habitats (Holm et al., 1977).

In Nepal, Mikania was first reported in 1963 in the eastern part of Nepal (Tiwari et al., 2005). Later on, it started spreading towards the western part, and now it has been recorded in the 20 Terai districts (Rai et al., 2012). M. micrantha is assessed as one of the six high-risk-posed invasive alien species in Nepal (Tiwari et al., 2005). In the Chitwan National Park (CNP), $M$. micrantha was found to be the most serious weed among the eight invasive alien species (IAS) in terrestrial ecosystem (Sapkota, 2006). The species is considered as the most problematic terrestrial invasive species in the tropical parts of

\footnotetext{
${ }^{1}$ International Union for Conservation of Nature, Lalitpur, Nepal. *E-mail: fr.sanyogbasnet@gmail.com

2 Institute of Forestry, Hetauda, Nepal
} 
Nepal (Poudel et al., 2005; Siwakoti, 2007).

In Nepal, this plant is known by different names such as Lahare Banmara and Lahare, and is found up to $1,300 \mathrm{~m}$ altitude. The plant has very low use values except as fodder during the lean period; cattle only consume it if nothing else is available, and people collect edible ferns that grow under the canopy of Mikania (Baral, 2004).

At present, the weed has vigorously invaded the core and buffer zone of the Chitwan National Park, threatening to biological diversity and ecosystem. The plant spreads appallingly fast in the moist part of the park, becoming dense within 8-10 years (Tiwari et al., 2005). Mikania is spreading freely without any hindrance in the lowland of Nepal.

Despite the current situation of the weed, quantitative data on the impacts and scale of the problems are lacking for the country. Therefore, this study aimed at comparing the effects of Mikania invasion on understory and over story plant diversity. The information regarding impact level could be useful to the stakeholders for common understanding. So, this paper also aims to create stakeholders' concern in such a serious biodiversity threat in the nation.

\section{Materials and methods}

\section{Study area}

The study was carried out in Barandabhar Buffer Zone Forest of Chitwan National Park (CNP) which is located at $27^{\circ} 37^{\prime} 02^{\prime \prime} \mathrm{N}$ latitude and $84^{\circ} 26^{\prime} 15^{\prime}$ "E longitude. The CNP is renowned for its unique diversity of flora and fauna. Recognizing its unique ecosystem of International significance, the UNESCO declared it as world heritage site in 1984 (MFSC, 2014). Barandabhar Forest Corridor is the only remaining natural forest with an area of $161 \mathrm{~km}^{2}$ that connects the CNP and the Mahabharat Range. The human population around the Corridor is over 50,000 (CBS, 2011), imparting excessive pressure on its ecosystems. Retention and restoration of such ecological corridors, linking protected areas, are considered essential in maintaining and restoring wildlife populations across the landscape.

The invasion is reported to have invaded the Park and the adjoining area in the 1980s and within the last 45 years, Mikania has colonized in large geographical area of the Park as well as the surrounding forest and the shrub-land, Mikania is being economically serious in and around the study area (Rai et al., 2012).

\section{Sampling design}

Stratified systematic sampling method was adopted for data collection. First of all, almost equal two distinct strata of Mikania-invaded and non-invaded areas were delineated visually with the help of GPS hand receiver. Then, systematic sample plots were allocated on both the strata for the collection of sample. Both the strata were of almost similar soil condition and stand age. Sample plots were established in both invaded and non-invaded areas for comparing the stand structure and plant diversity at species level. The study area comprises the tropical Shorea robusta forest. The major tree species found are Shorea robusta, Terminalia tomentosa, Bombax ceiba, Dalbergia sissoo, Trewia nudiflora and so on.

\section{Data collection}

Fourteen nested circular sample plots were established in each stratum for the measurement of tree, pole, sapling and regeneration (Fig. 1). Thus, a circular plot of $500 \mathrm{~m}^{2}$ area (12.6 m radius) was established for tree (a) within which nested plots of $100 \mathrm{~m}^{2}$ (5.6 m radius), $25 \mathrm{~m}^{2}$ ( $2.8 \mathrm{~m}$ radius) and $10 \mathrm{~m}^{2}$ (1.8 $\mathrm{m}$ radius) were established for pole (b), sapling (c) and regeneration (d), respectively (DoF, 2004). Species-wise diameters at breast height (DBHs) and heights were measured and recorded in the case of trees and poles. Similarly, DBH was measured and recorded in the case of saplings whereas species-wise plant numbers were recorded in the case of regeneration.

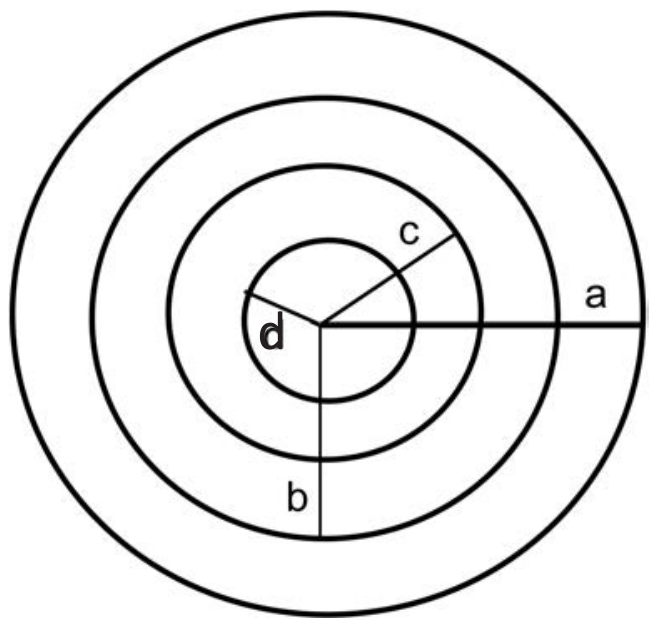

Fig. 1 : A nested circular sample plot 


\section{Data analysis}

The data collected from the field were analyzed by assessing the regeneration status together with the sapling diversity and density. The basal areas of the trees and poles per hectare was computed to assess the over-story tree density. For the calculation of plant diversity of the study area, Simpson's Index (D) was adopted.

Simpson's Index $(\mathrm{D})=\sum(\mathrm{Pi})^{2}$,

Where, $\mathrm{Pi}=$ Proportion of individual species in the community i.

Species distribution and tree basal area were calculated as follows:

$\underset{(\mathrm{N} \text { per ha })}{\text { 1. Species density }}=\frac{\text { No. of regeneration }}{\text { Area of a plot }} \times 10000$

2. Individual tree basal area $(B A)=\frac{\pi d^{2}}{4}$

Where, $\mathrm{d}=$ diameter at breast height.

After the calculation of various attributes (density, basal area per ha) of growing stock, the two strata were compared using various statistical tests (t-test, independent sample test).

\section{Results and discussion}

\section{Plant diversity at seedling and sapling stages}

The Simpson's Index values of the Mikania invaded and non-invaded strata at regeneration i.e. seedling level were found to be 0.1806 and 0.0681 , respectively while those at sapling level were found to be 0.3406 and 0.3192 , respectively. As Simpson's Index values are inversely related to the plant diversity, the plant diversities at sapling and seeding stages were found to be higher in the non-invaded area.

The climber and shoots of Mikania was found to be totally obstructing the opening to ground level which might have restricted germination and growth of its saplings and seedlings.

\section{Seedling density}

The per hectare density of the seedlings in the noninvaded area $(19,000 / \mathrm{ha})$ was found to be almost six times more than that in the invaded area $(3,214 /$ ha). Independent sample t-test revealed that the seedings per hectare was significantly higher in the non-invaded area than in the invaded area at $5 \%$ level of significance $(P \leq 0.001 ; N=14)$.

The coverage of $M$. micrantha was found to have reduced the growth as well as germination of the tree species, resulting in the poor density of the seedlings and saplings of the tree secies. The lower seedling density in the invaded area showed the adverse effects of Mikania on the growth and regeneration of forest crops; the invasion of Mikania was found to have created shade and lack of openings on the ground, resulting in the low density of the seedlings.

\section{Sapling density}

The per hectare density of the saplings was found to be higher in the non-invaded area (149/ha) than in the invaded area (60/ha). This showed that the growth of the understory was severely affected by the invasion of Mikania. Independent t-test revealed that the saplings per hectare was significantly higher in the non-invaded area than in the invaded area at 5\% level of significance $(P=0.015 ; N=14)$.

The difference could be due to the effect of the invasion of Mikania on the germination of the plants as well as the growth of the seedlings, resulting in the lower density of saplings in invaded strata.

\section{Basal area of pole per hectare}

The basal area of the poles per hectare was more than three times higher in the non-invaded (5.6 $\left.\mathrm{m}^{3} / \mathrm{ha}\right)$ area than in the invaded area $\left(2.2 \mathrm{~m}^{3} / \mathrm{ha}\right)$. Also, it was found significantly higher in the noninvaded area than in the invaded area at 5\% level of significance $(P=0.002 ; N=14)$. The diameter growth and basal area formation was found to be significantly less in the invaded area than in the invaded area. The invasion of Mikania might have affected upon the phenological process of the plant species, its development and cambium formation might have been also affected. That is why the density of poles and its individual size was found to be comparatively lower in the invaded area.

\section{Tree basal area per hectare}

The non-invaded area had more than two times more basal area per hectare than in the invaded area (invaded: $2.2 \mathrm{~m}^{3} / \mathrm{ha}$; non-invaded: $5.6 \mathrm{~m}^{3} /$ 
ha). It was also found to be significantly higher in the non-invaded area at 5\% level of significance $(P=0.024 ; N=14)$, indicating significantly higher basal area growth in the non-invaded area than in the invaded area.

As in the case of the pole basal area, the invasion might have great impact upon the phenological process of the trees, resulting in the slow growth in the overall basal area of the forest stand in the invaded area.

\section{Conclusion}

The study has revealed the current scenario of plant diversity and stand structure in Mikaniainvaded and non-invaded areas. It this study, the plant diversity and composition at undergrowth level was found to be significantly affected from the invasion whereas the non-invaded area had better growth condition. The invasion of Mikania had created serious ecological problem in forest management, both in terms of diversity and productivity. The findings of the study have, therefore, clearly indicated the adverse impact of Mikania invasion on forest growth. Therefore, regular treatment and control mechanism should be developed so as to control invasion of Mikania and other invasive species in a forest invaded by such invasive species and to improve the forest condition.

\section{Acknowledgements}

We sincerely thank Chitwan National Park and Baradhabar Buffer Zone Forest Management Committee for their support in data collection during field works. We would also like to thank Md. Yusuf Ansari, Campus Chief, Institute of Forestry, Hetauda Campus and Mr. Rajiv Kumar Jha for their guidance and recommendation.

\section{References}

Adhikari, B., Di Falco, S. and Lovett, J. C. 2004. Household characteristics and forest dependency: evidence from common property forest management in Nepal. Ecological Economics 48 (2): 245-257.

Baral, H. S. 2004. Mikania micrantha Weed Invasion in Nepal. Paper presented at First National Stakeholders' Workshop, Kathmandu, Nepal, 25 Nov, 2004.

Bhatta, S. R. 2006. Grassland Management in Royal Chitwan National Park:
Biodiversity Conservation Effort in Nepal. International Centre for Integrated Mountain Development, Lalitpur, Nepal.

CBS. 2011. Nepal Population Census Report, 2011. Central Bureau of Statistics (CBS), Kathmandu, Nepal.

DoF. 2004. Community Forest Inventory Guidelines. Government of Nepal, Ministry of Forests and Soil Conservation, Department of Forests (DoF), Kathmandu, Nepal.

Holm, L. G., Plucknett, D. L., Pancho, J. V. and Herberger, J. P. 1977. The World's Worst Weeds: Distribution and Biology. University Press of Hawaii, USA.

Holmes, W. C. 1982. Revision of the old world Mikania (Compositae). Botanische Jahrbücher 103 (2): 211-246.

ISSG. 2005. Ecology of Mikania micrantha. Invasive Species Specialist Group Database. http://www.issg.org/database/species// ecology.asp?si=42 accessed on 4 April, 2015.

MFSC. 2014. Nepal Biodiversity Strategy and Action Plan (2014-2020). Government of Nepal, Ministry of Forests and Soil Conservation (MFSC), Kathmandu, Nepal.

Poudel, A., Baral, H. S., Ellison, C. A., Subedi, K., Thomas, S. and Murphy, S. 2005. Mikania micrantha Weed Invasion in Nepal. A Summary Report of the First National Workshop for Stakeholders held on 25 November, Kathmandu, Nepal.

Rai, R. K., Scarborough, H., Subedi, N. and Lamichhane, B. 2012. Invasive plants - do they devastate or diversify rural livelihoods? Rural farmers' perception of three invasive plants in Nepal. Journal for Nature Conservation 20 (3): 170-176.

Sapkota, L. N. 2006. Invasive Alien Species in Chitwan National Park, Nepal. M.Sc. Thesis, Institute of Forestry, Tribhuvan University, Pokhara, Nepal.

Siwakoti, M. 2007. Mikania weed: a challenge for conservationists. Our Nature 5: 70-74.

Tiwari, S., Adhikari, B., Siwakoti, M. and Subedi, K. 2005. An Inventory and Assessment of Invasive Alien Plant Species of Nepal. IUCN-The World Conservation Union, Kathmandu, Nepal. 